\title{
Estrogen receptor subtypes dictate the proliferative nature of the mammary gland
}

\author{
Genevieve V Dall', Samuel Hawthorne², Yashar Seyed-Razavi², Jessica Vieusseux', Wanfu Wu³, \\ Jan-Ake Gustafsson³, David Byrne4, Leigh Murphy5, Gail P Risbridger1,2 and Kara L Britt1,6 \\ ${ }_{1}^{1}$ Peter MacCallum Cancer Centre, Melbourne, Australia \\ 2Department of Anatomy and Developmental Biology, Monash University, Melbourne, Australia \\ 3Department of Biology and Biochemistry, University of Houston, Houston, Texas, USA \\ ${ }^{4}$ Department of Pathology, Peter MacCallum Cancer Centre, Melbourne, Australia \\ 5 University of Manitoba, Winnipeg, Canada \\ ${ }^{6}$ The Sir Peter MacCallum, Department of Oncology, University of Melbourne, Melbourne, Australia \\ Correspondence should be addressed to K L Britt: kara.britt@petermac.org
}

\section{Abstract}

Estrogen induces proliferation of breast epithelial cells and is responsible for breast development at puberty. This tightly regulated control is lost in estrogen-receptorpositive (ER+) breast cancers, which comprise over $70 \%$ of all breast cancers. Currently, breast cancer diagnosis and treatment considers only the $\alpha$ isoform of ER; however, there is a second ER, ER $\beta$. Whilst ER $\alpha$ mediates estrogen-driven proliferation of the normal breast in puberty and breast cancers, ER $\beta$ has been shown to exert an anti-
Key Words
- parity
- estrogen receptor alpha
- estrogen receptor beta
- mammary gland
- breast cancer

proliferative effect on the normal breast. It is not known how the expression of each ER (alone or in combination) correlates with the ability of estrogen to induce proliferation in the breast. We assessed the levels of each ER in normal mouse mammary glands subdivided into proliferative and non-proliferative regions. ER $\alpha$ was most abundant in the proliferative regions of younger mice, with $\operatorname{ER} \beta$ expressed most abundantly in old mice. We correlated this expression profile with function by showing that the ability of estrogen to induce proliferation was reduced in older mice. To show that the ER profile associated with breast cancer risk, we assessed ER expression in parous mice which are known to have a reduced risk of developing ER $\alpha$ breast cancer. ER $\alpha$ expression was significantly decreased yet co-localization analysis revealed ER $\beta$ expression increased with parity. Parous mice had less unopposed nuclear ER $\alpha$ expression and increased levels of ER $\beta$. These changes suggest that the nuclear expression of ERs dictates the proliferative nature of the breast and may explain the decreased breast cancer risk with parity.

\section{Introduction}

Estrogen has long been linked to breast cancer stimulation and underlies the effectiveness of anti-estrogen therapies such as tamoxifen to block the growth and recurrence of hormonally responsive breast cancer. At present, antiestrogen therapy focuses on blocking the action of $\mathrm{ER} \alpha$, one of two ER subtypes present within the breast, due to its overexpression in 70\% of breast cancers (Masood 1992). $\mathrm{ER} \alpha$ is expressed within a subset of luminal epithelial cells in the mouse mammary epithelium and mediates the proliferative effects of estrogen (Pettersson et al. 
2000, Ström et al. 2004). A series of ER $\alpha$-deficient mouse models have revealed that it is required for mammary ductal elongation, pregnancy-induced tertiary branching and the proliferation and maintenance of differentiating alveolar cells (Bocchinfuso et al. 2000, Dupont et al. 2000, Feng et al. 2007). The role of ER $\alpha$ in cancer development is evidenced in its overexpression in the majority of breast cancers and increased expression in the breast tissue of populations at high breast cancer risk (Lawson et al. 1999). Furthermore, deregulation of ER $\alpha$ expression in mammary epithelial cells is sufficient to increase proliferation and development of ductal carcinoma in situ (Frech et al. 2005). Likewise, loss of ERo is associated with a reduction in mammary tumorigenesis in transgenic mice (Bocchinfuso \& Korach 1997, Hewitt et al. 2002).

$\mathrm{ER} \beta$, the product of a second estrogen receptor gene (ESR2) located on a different chromosome (Gosden et al. 1986, Enmark et al. 1997), has almost complete homology to the original ER $\alpha$ in the DNA-binding domain (97\%), and part homology to the ligand-binding domain (55\%) (Li et al. 2004). In contrast to ER $\alpha$, high expression of ER $\beta$ correlates with decreased proliferative markers and longer disease-free survival of breast cancer (Roger et al. 2001, Omoto et al. 2002, Esslimani-Sahla et al. 2004, Myers et al . 2004a, Gruvberger-Saal et al. 2007, Sugiura et al. 2007, Leygue \& Murphy 2013, Hieken et al. 2015) yet its expression is rarely considered for clinical management of disease.

ER $\beta$ is expressed in high (near ubiquitous) levels throughout the epithelium of the breast, yet mice deficient in ER $\beta$ appear to have a normal mammary histology (Krege et al. 1998). ER $\beta$ appears to play a more subtle role in mammary gland development, mediating the terminal differentiation of the gland during pregnancy and lactation as well as an effect on intercellular junctions and proliferation (Forster et al. 2002). Over the last decade, evidence for an anti-proliferative role for ER $\beta$ in numerous organs has also emerged (Risbridger et al. 2007, Leygue \& Murphy 2013) and work by ourselves and others has demonstrated a role for ER $\beta$ in negatively regulating the estrogen-induced pro-proliferative actions of ER $\alpha$. For example, if ER $\beta$ and ER $\alpha$ are co-expressed in a cancer cell, estradiol and phytoestrogens have been shown to reduce proliferation in breast and prostate cancer cell lines in vitro (Ström et al. 2004, Powell et al. 2012). Coupled with the aforementioned observations of high ER $\beta$ expression correlating with less aggressive breast cancer cases, the ratio of ER $\alpha: E R \beta$ in clinical breast cancers specimens has also been shown to increase with increasing stage of breast cancer (Powell et al. 2012). However, support for this anti-proliferative role of ER $\beta$ has largely come from work in the setting of breast cancer, and there remains a limited understanding of the interaction of the ERs in the normal breast.

Transcript and protein levels of ER $\alpha$ and ER $\beta$ have been assessed in mammary tissue of rats throughout development (Saji et al. 2000, 2001), showing a widespread expression of ER $\beta$ throughout development except during the proliferative phase of pregnancy when ER $\beta$ levels were lost. However, the protein expression work was performed at low resolution and does not allow the assessment of subcellular localization of each ER. Here, we have assessed the levels of expression of ER $\alpha$ and ER $\beta$ in the mouse mammary gland and correlated expression and estradiol sensitivity with proliferation rate of the gland in different regions and at different ages. We show for the first time that mice at low risk of breast cancer (parous mice) have a less proliferative ER signature; low $E R \alpha$ and high nuclear expression of ER $\beta$. We propose from this work that the levels of both receptors within the normal breast epithelium are important in determining the proliferative nature of the gland and could be used to predict developmental stages of oncogenic vulnerability.

\section{Materials and methods}

\section{Animals}

All animal work was completed under Monash University Animal Ethics Committee approval. All mice were housed in microisolated cages and provided with water and chow ad libitum. 5- to 6-week-old FVB females were bred with similarly aged FVB males. Pregnant mothers carried their offspring to term and underwent full nursing (lactation for 3 weeks) before pups were removed at the normal weaning age (21 days). Mothers were then left for 10 weeks to return to a resting parous state, avoiding the transient increased triple negative breast cancer risk period that immediately follows pregnancy (Schedin 2006). Age-matched virgin FVB females were used as controls. For estrogen sensitivity studies, mice at 6 to 9 weeks of age were ovariectomized and treated with estrogen or vehicle 7 days later, a time point selected based on assays by Haslam (Haslam 1989).

\section{Tissue collection}

Each animal assessed was taken at the estrus stage of the cell cycle as determined by vaginal smear except where estrus cyclicity was not yet established. Fourth mammary glands were excised and divided into 3 portions (proximal 
to the nipple, middle region and distal tips) to compare receptor expression and proliferative response between different regions of the mammary gland. We assessed these three regions separately as the distal tips have been shown to be the most proliferative (Russo \& Russo 1980). Mammary gland portions were formalin fixed, paraffin embedded and sectioned prior to immunolabeling.

\section{Antibodies}

Primary antibodies against ER isoforms were mouse monoclonal anti human ER $\alpha$ 1:40 (clone ID5, DAKO) and chicken anti human ER $\beta$ 1:50 a kind gift from JanAke Gustafsson. The specificity of chicken polyclonal 503 IgY ER $\beta$ antibody has been tested previously using peptide pre-absorption in rat tissue (Saji et al. 2000) and also in ER $\beta$ knockout mice (Maneix et al. 2015). It recognizes mouse ERbeta and mouse ER $\beta 18$ aa ins but does not pick up human ER $\beta 2$ (or ER $\beta c x$ ) (Ogawa et al. 1998). We performed our own validation using MDA-MB-231 cells (which do not express ER $\beta$ ) and MDA-MB-231 cells overexpressing ER $\beta 1$ (Supplementary Methods and Supplementary Fig. 1, see section on supplementary data given at the end of this article) and show that only MDA-MB-231 cells expressing ER $\beta 1$ showed positive staining. We also performed validation studies with the CWK ER $\beta$ antibody (CWK-F12, DSHB) generated by B Katzenellenbogen that was validated as specific for ER $\beta$ using rapid immunoprecipitation mass spectrometry of endogenous protein (RIME) (Nelson et al. 2017). Both the ER $\alpha$ and ER $\beta$ primary antibodies also have demonstrated cross-reactivity to mouse tissue in previous studies (Weihua et al. 2001, Dall et al. 2017). Rat monoclonal anti BrDU antibody (clone BU1/75 (ICR1), AbD Serotec, Kidlington, UK), rabbit polyclonal anti-phosphorylated Ki67 (Leica Biosystems) and purified mouse anti-Ecadherin (clone 36/E-Cadherin, BD Biosciences, Franklyn Lakes, NJ, USA) were also used. For immunohistochemistry, biotinylated secondary antibodies were used correlating to the appropriate isotype. For immunofluorescence, antimouse IgG1 555 fluorescently labeled secondary antibody was used for ER $\alpha$, anti-chicken 488 fluorescently labeled secondary antibody was used for ER $\beta$ and anti-mouse IgG2a 647 fluorescently labeled secondary antibody was used for E-Cadherin (Invitrogen).

\section{Immunolabelling on paraffin sections}

Sections were dewaxed and rehydrated through graded alcohols into water. Heat-mediated antigen retrieval was performed in $0.01 \mathrm{M}$ citrate buffer ( $\mathrm{pH}$ 6.0) using either a pressure cooker for ER $\alpha$, ER $\beta$ and Ki67 or microwave for BrDU. Where appropriate endogenous peroxidase blocking by incubating sections in 3\% hydrogen peroxide (Merck Millipore) in methanol. Non-specific immunoreactivity was blocked by incubation with mouse immunoglobulin blocking reagent (M.O.M. Kit, Vector Laboratories, Peterborough, UK) and CAS block (Invitrogen). Primary antibodies as detailed earlier were applied to sections overnight at $4^{\circ} \mathrm{C}$. Sections were washed several times in $0.05 \% \mathrm{TBS} /$ tween and then incubated in appropriate secondary antibodies for $30 \mathrm{~min}$ up to $1.5 \mathrm{~h}$ at room temperature. Sections were washed using $0.05 \% \mathrm{TBS} /$ tween. For immunohistochemical labeling, sections were treated with avidin-biotin-HRP complex (ABC-HRP; DAKO A/S) prior to protein localization using diaminobenzidine (liquid DAB; Dako). Sections were then counterstained and coverslipped for imaging. The CWK-F12 ER $\beta$ antibody was diluted to 1:25 and used on the Ventana Benchmark Ultra Autostainer. Briefly, tumor cell lines were deparaffinized, antigen retrieval done with Cell Conditioner 1 (CC1) for $40 \mathrm{~min}$ at $100^{\circ} \mathrm{C}$ and pre-primary peroxidase inhibitor for $5 \mathrm{~min}$ at room temperature. Primary antibody incubations were completed for $60 \mathrm{~min}$ at room temperature. Visualization on the autostainer was performed with OptiView DAB IHC Detection Kit (Ventana Medical Systems, Tucson, AZ, USA) and then counterstained with Mayer's Hemotoxylin (Amber Scientific, Midvale, Australia) for $60 \mathrm{~s}$. We also tried manual staining with the same CWK-F12 antibody and pressure cooking, but staining was not successful.

For immunofluorescence, sections were stained with DAPI (Roche)/PBS to label nuclei before coverslipping in Vectasheild mounting media (Vector Laboratories) for imaging.

\section{Image capture}

Immunohistochemical staining was imaged and captured on an Olympus BX-51 microscope (Olympus). All immunofluorescent sections were examined at room temperature using a NIKON CI inverted confocal microscope. PMT levels for all channels were set using a positive control young virgin mammary gland section. All images, including negative controls, were then taken with these settings to allow cross comparison. Images of sections were obtained using $60 \times / 1.40-0.60$ oil $\lambda$ lenses and captured via NIS elements image acquisition software. Multicolor images were collected sequentially in three 
channels and co-localization overlays were generated using ImageJ software.

\section{Quantification of ER $\alpha$ expression}

Tissue blocks from each portion of the mammary gland were completely sectioned and a uniform systematic random sampling scheme was employed to quantitate ERo-positive cells as described in previous literature (Bianco et al. 2006), where every 20th section was selected for immunostaining. Tissues from all groups were processed in the same immunohistochemical assay to eliminate inter-assay variation. Once stained, quantification of immunoreactivity was performed using a BioPrecision2 microscope stage (LUDL), 99A400 Focus drive (LUDL), MAC5000 Controller (LUDL) and ND-281 Encoder (Heidenhain) coupled to an Olympus BX-51 microscope (Olympus). Sections were examined at 10x magnification, mapped to define tissue boundaries, and sampled at pre-determined intervals along the $x$ and $y$ axis using a single point grid counting frame to allow sampling of fraction of $10-40 \%$ of the selected tissue sections. Using brightfield imaging under $40 \times$ magnification, positive cells were scored and totaled for each representative section, and then compiled for each region (proximal, middle, distal) for each animal. The results are expressed as the percentage of total cells counted. The images were captured using a PixeLink PL-623C digital camera (PixeLink) coupled to a computer.

\section{Quantification of ER $\alpha / E R \beta$ co-localization}

At least 5 images from each of $n=4-5$ nulliparous or parous animals were assessed for the subcellular localization of ER $\alpha$ and ER $\beta$. DAPI and E-cadherin staining were used to distinguish nuclear and cytoplasmic regions of the cell (Supplementary Fig. 2). The total number of epithelial cells was counted for each image as were the ER $\alpha+$, ER $\beta+$ and ER $\alpha / E R \beta$ double positive cells. The percentages of ER expressing cells were expressed as a fraction of total cells.

\section{Quantification of BrDU}

At least 5 images from each of $n=5$ mice at 6 or 9 weeks of age treated with oil or estradiol were taken and the percentage of BrDU-positive epithelial cells as a function of the total epithelial cells was determined in each section.
Determining the proliferative response to exogenous estrogen

The responsiveness of the mammary gland to the proliferative effects of estradiol can be assessed using ovariectomized mice treated with oil or estradiol (Haslam 1989). Pubertal or 9-week-old mice were ovariectomized and treated with either vehicle (peanut oil, Sigma), or one of three doses of estradiol: low $(0.1 \mu \mathrm{g}$ per gram body weight), medium $(1 \mu \mathrm{g} / \mathrm{gram} \mathrm{BW})$ or high $(10 \mu \mathrm{g} / \mathrm{gram} \mathrm{BW})$ 7 days post-surgery. All mice were killed after $48 \mathrm{~h}$ but were treated with $50 \mu \mathrm{g} / \mathrm{g}$ body weight bromodeoxyuridine (BrDU, Sigma) intraperitoneal $2 \mathrm{~h}$ prior to collection to allow proliferation to be assessed.

\section{Statistical analysis}

Results are presented as mean \pm standard error of the mean (s.E.M.). Stereological assessment of ER $\alpha$ expression was tested for normality using a D'Agostino-Pearson omnibus test and then a non-parametric Mann-Whitney $U$ test was used to assess statistical differences (GraphPad Prism software). For co-localization analysis of ER $\alpha$ and ER $\beta$, a 2-way ANOVA with Tukey's multiple comparisons test was used to assess statistical differences. Differences between experimental and control groups were considered significant at $P<0.05$.

\section{Results}

The mouse mammary gland shows structural differences including duct thickness, side branching and endowment of proliferative subtending branches in the regions located distal from the nipple (Russo \& Russo 1980). To explore ER $\alpha$ and ER $\beta$ expression throughout the mammary gland, the tissue was divided into 3 equal portions (proximal, middle and distal regions) and the expression assessed according to each portion. The expression of ER $\alpha$ was limited to a subset of epithelial cells throughout the gland at all ages. However, at 4-6 weeks of age, the number of ERo-expressing cells was higher than that in the mature adult mammary gland (Fig. 1). The number of ERo-expressing cells in young mice was also higher in the more distal regions than that in the proximal regions (Fig. 1A (ii, iii) and B (ii, iii)).

In contrast to $\mathrm{ER} \alpha, \mathrm{ER} \beta$ expression was ubiquitously expressed in all epithelial cells of the mouse mammary gland, at all ages (Fig. 2). Unlike ER $\alpha$ expression, ER $\beta$ was observed at equal levels across all regions of the ductal 


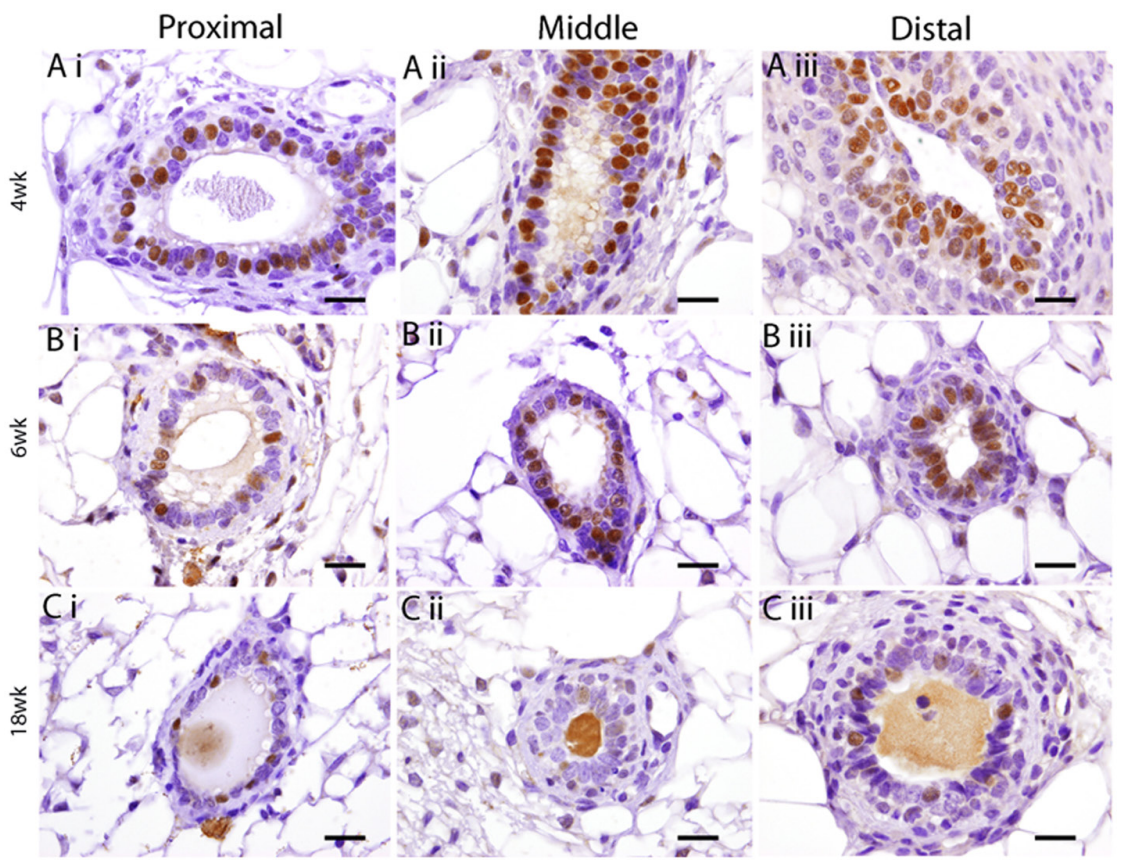

\section{Figure 1}

Estrogen receptor (ER) $\alpha$ staining is more abundant in mammary glands from young mice. ER $\alpha$ immunohistochemical staining in 4-week (A), 6-week (B) and 18-week (C) old mice. Expression was assessed in various regions of the gland that were proximal (i), middle (ii) and distal (iii) to the nipple. Scale represents $20 \mu \mathrm{m}$. A full-colour version of this figure is available at https://doi. org/10.1530/JOE-17-0582. tree including the terminal end buds (TEBs) (Fig. 2A (iii) and B (iii)).

To assess whether the expression levels of $\mathrm{ER} \alpha$ and $\operatorname{ER} \beta$ were indicative of the proliferative nature of the mammary gland, 4-, 6- and 18-week old mammary glands were stained with $\mathrm{Ki} 67$ as a marker of cell division. As shown in Fig. 3, Ki67 expression was largely absent in the 4-week-old mammary gland (Fig. 3B) but increased in abundance in the 6-week-old mammary gland.
By 18 weeks, the mammary gland exhibited modest Ki67 expression (Fig. 3C). Correlating with the increase in ER $\alpha$ expression observed in the middle and distal regions of the 6-week-old mammary gland (Fig. 1B (ii, iii)), Ki67 was also observed to be highest in these regions (Fig. 3B (ii, iii)).

To investigate if ER expression profiles correlated with the ability of estrogen to functionally induce the increase in proliferation observed in Fig. 3, we used an assay of estrogen sensitivity originally used to define when the

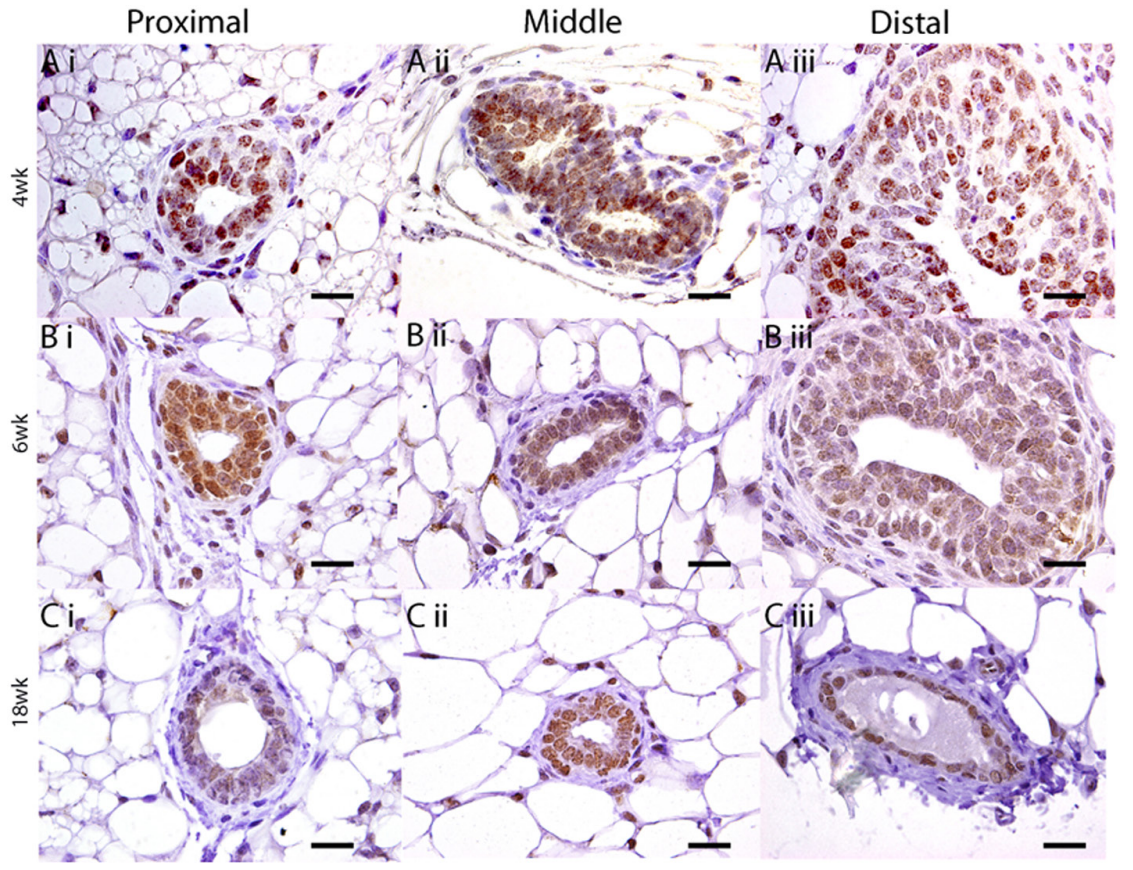

Figure 2

Estrogen receptor (ER) $\beta$ staining is similar across all ages and regions of the mammary gland. ER $\beta$ immunohistochemical staining in 4-week (A), 6-week (B) and 18-week (C) old mice. Expression was assessed in various regions of the gland that were proximal (i), middle (ii) and distal (iii) to the nipple. Scale represents $20 \mu \mathrm{m}$. A full-colour version of this figure is available at https://doi. org/10.1530/JOE-17-0582.

$$
\begin{array}{lr}
\text { http://joe.endocrinology-journals.org } & \text { ○ } 2018 \text { Society for Endocrinology } \\
\text { https://doi.org/10.1530/JOE-17-0582 } & \text { Published by Bioscientifica Ltd. } \\
& \text { Printed in Great Britain }
\end{array}
$$



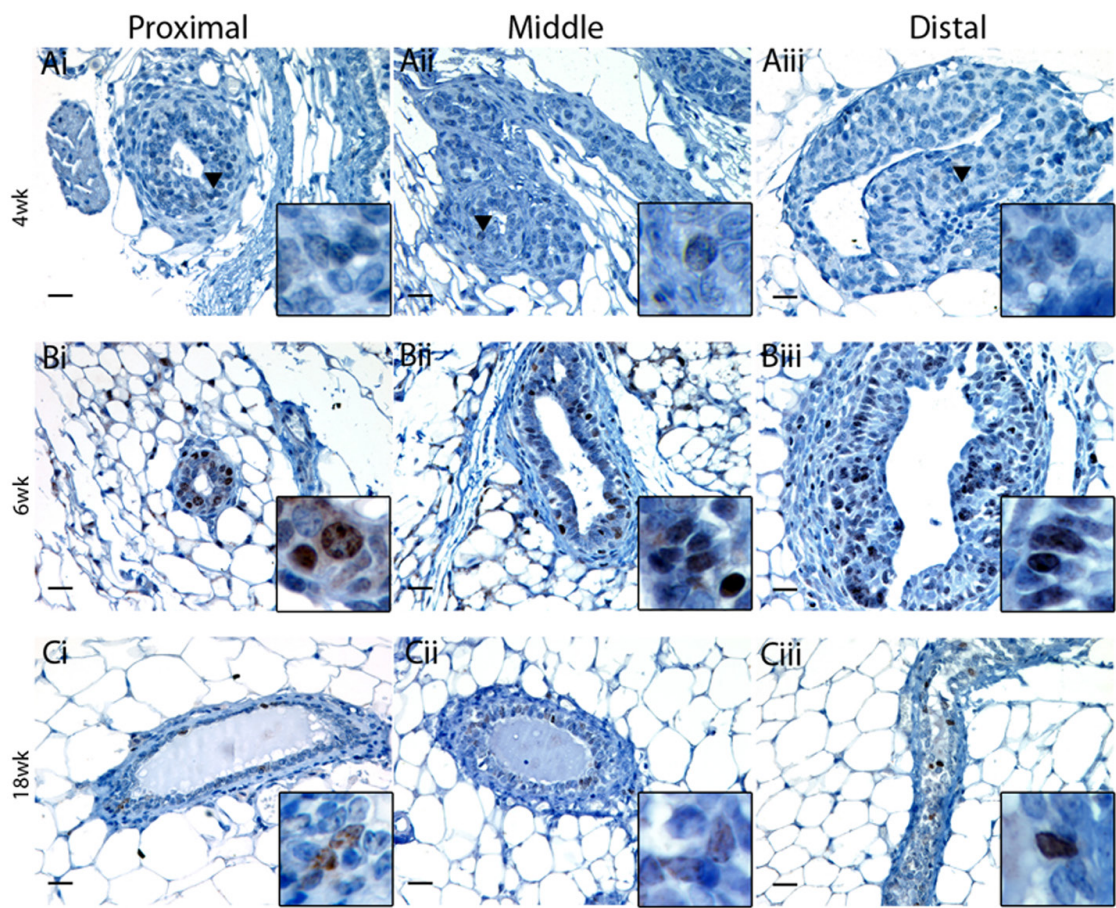

\section{Figure 3}

Ki67 staining is more abundant in mammary glands from 6-week old mice. Ki67 immunohistochemical staining in 4-week (A), 6-week (B) and 18-week old mice. Expression was assessed in various regions of the gland that were proximal (i), middle (ii) and distal (iii) to the nipple. Scale represents $20 \mu \mathrm{m}$. A full-colour version of this figure is available at https://doi. org/10.1530/JOE-17-0582. mouse mammary gland first becomes responsive to the estrogen-induced proliferation (Haslam \& Shyamala 1980, Haslam 1989). Estrogen treatment $(0.1 \mu \mathrm{g} / \mathrm{g} \mathrm{BW})$ induced proliferation (indicated by detection of $\mathrm{BrDU}$ ) in the epithelial and stromal cells across the mammary glands of 6-week-old animals that had been ovariectomized (Fig. 4), with greatest effect in the distal tips which had the highest ER $\alpha$ to ER $\beta$ ratio (Figs 1B (iii) and 2B (iii)).

Pubertal mice are presumed to be ultra-sensitive to estrogen whilst they undergo ductal elongation to fill the mammary fat pad. Consistent with this, the adult mammary tissue showed a less proliferative ER profile compared to the 6-week-old mammary gland (decreased ER $\alpha$ (Fig. 1C) and increased ER $\beta$ (Fig. 2C)). To confirm that the adult mice were functionally less sensitive to estrogen by nature of their altered ER profile, we used the in vivo assay of estrogen sensitivity described earlier. At the same dose of estrogen used to successfully stimulate epithelial cell proliferation in 6-week-old animals (Fig. 4), whilst the stroma did show a proliferative response, the epithelial cells in 9-week-old adult mice were unresponsive. This agrees with previous work showing that the epithelial cells are less sensitive than stromal cells to an estrogen stimulus (Haslam 1989). Instead they required 2 orders of magnitude higher dose to induce epithelial cell proliferation (Fig. 5). Even at this higher dose $(10 \mu \mathrm{g} / \mathrm{g}$ $\mathrm{BW})$, the adult mice showed a reduced response to estrogen-induced epithelial cell proliferation compared to pubertal animals (Fig. 6).

\footnotetext{
http://joe.endocrinology-journals.org https://doi.org/10.1530/JOE-17-0582
}

(c) 2018 Society for Endocrinology Published by Bioscientifica Ltd. Printed in Great Britain
If the proliferative nature of the mammary gland aligns with breast cancer risk (increased proliferation=increased risk), we would expect the ER expression profile to reflect this. To test such a prediction, we assessed a mouse model of decreased ER+ breast cancer risk, parity (Russo et al. 1991, Medina \& Smith 1999). Parous mice were generated by mating 6-week-old females and allowing them one cycle of pregnancy, lactation and involution before a 10-week period, allowing their mammary glands to return to pre-pregnant ductal architecture. ER $\alpha$ in the parous glands was decreased compared to age- and estrous-cyclestage-matched nulliparous controls (Fig. 7). We sectioned the entire mammary gland from 5 animals and performed stereological quantification similar to the protocol we have used previously to assess follicle numbers in mouse ovaries (Myers et al. 2004b). Our analysis allowed at least 100 cells per section to be assessed for ER $\alpha$ positivity (Fig. 7A, B and C). The number of ER $\alpha+$ cells was significantly reduced in the middle and distal regions $(P=0.03)$ (Fig. 7D).

To assess whether the subcellular locations of ER $\alpha$ and ER $\beta$ aligned with proliferation, we performed immunofluorescence staining on parous and nulliparous mammary glands (Fig. 8). The ER $\alpha$ expression was again observed to be decreased in parous mammary glands compared to age-matched controls (Fig. 8B and E). ER $\beta$ expression was observed to be ubiquitously expressed throughout both parous and nulliparous glands (Fig. 8C and F). Due to the ubiquitous expression of 


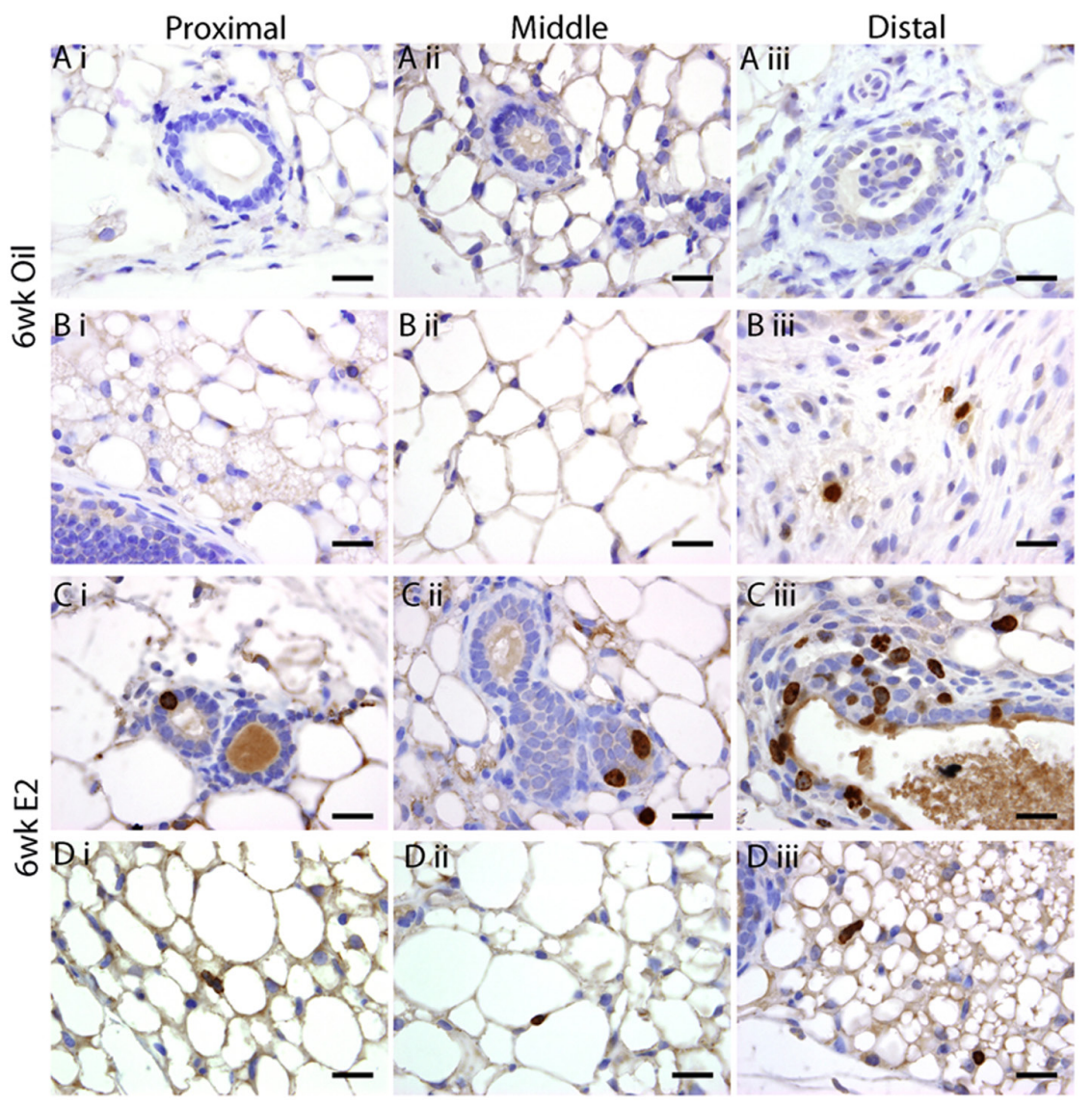

\section{Figure 4}

High estrogen sensitivity in young (6 week old) mice. BrDU staining in the mammary glands of mice treated with either peanut oil control (A and $B$ ) or $0.1 \mu \mathrm{g} / \mathrm{g}$ BW $17 \beta$ estradiol (C and D). Epithelial ( $A$ and $C$ ) and stromal staining ( $B$ and D) is shown within regions of the gland proximal (i), middle (ii) and distal (iii) to the nipple. Scale represents $20 \mu \mathrm{m}$. A full-colour version of this figure is available at https://doi.org/10.1530/ JOE-17-0582.
ER $\beta$ in mammary epithelial cells, we performed all immunofluorescence on the same day and took all images using the same laser strength and detector settings, allowing quantification of ER $\alpha$ and ER $\beta$ expression in parous and age-matched nulliparous glands. As shown in Fig. 8F, the intensity of ER $\beta$ expression was higher in parous mammary glands compared to nulliparous.

When we assess co-localization of the ERs in parous and nulliparous mammary glands (Fig. 9 and Supplementary Fig. 2), ER $\alpha$ expression was restricted to the nucleus; however, ER $\beta$ showed either cytoplasmic or nuclear expression. In nulliparous mice, the percentage of cells expressing ER $\alpha$ alone was 9, 20 and 15\% in proximal, middle and distal regions, respectively (Fig. 9C (i)). In accordance with our stereology findings, the parous glands had significant reductions in ER $\alpha$-expressing cells in the middle and distal regions (28- and 13- fold reduction, respectively). In contrast, the percentage of cells with unopposed nuclear ER $\beta$ expression was significantly higher in parous mammary glands compared to nulliparous across all regions (increase of 3-, 2- and 4-fold for proximal, middle and distal, respectively)
(Fig. 9C (ii)). The percentage of cells with nuclear ER $\alpha$ and $\operatorname{ER} \beta$ co-expression was unchanged between parous and nulliparous mammary glands (Fig. 9C (iii)). Cells with nuclear ER $\alpha$ and cytoplasmic ER $\beta$ were significantly reduced in parous mammary glands compared to nulliparous in the proximal region only (9-fold decrease) (Fig. 9C (iv)). The middle and distal regions also showed a trend for a decrease in the parous mammary glands but this did not reach significance. The level of cytoplasmic ER $\beta$ alone expression was variable across the gland and was not significantly altered with parity (Fig. 9C (v)). We did not observe in any of our normal mammary sections co-localization of the ERs in the same sub-nuclear location. Even when both receptors were expressed in the nucleus, ER $\alpha$ was restricted to the euchromatin, and $\operatorname{ER} \beta$ was present in the heterochromatin (Fig. 9A inset).

We assessed whether the changes in $\operatorname{ER} \alpha$ and $\operatorname{ER} \beta$ due to parity lead to a decrease in proliferation in the mammary gland using Ki67. The parous animals showed significantly lower levels of Ki67 staining compared to nulliparous mammary glands, indicating low levels of proliferation induced by parity (Fig. 10). http://joe.endocrinology-journals.org https://doi.org/10.1530/JOE-17-0582
(C) 2018 Society for Endocrinology Published by Bioscientifica Ltd.
Printed in Great Britain 

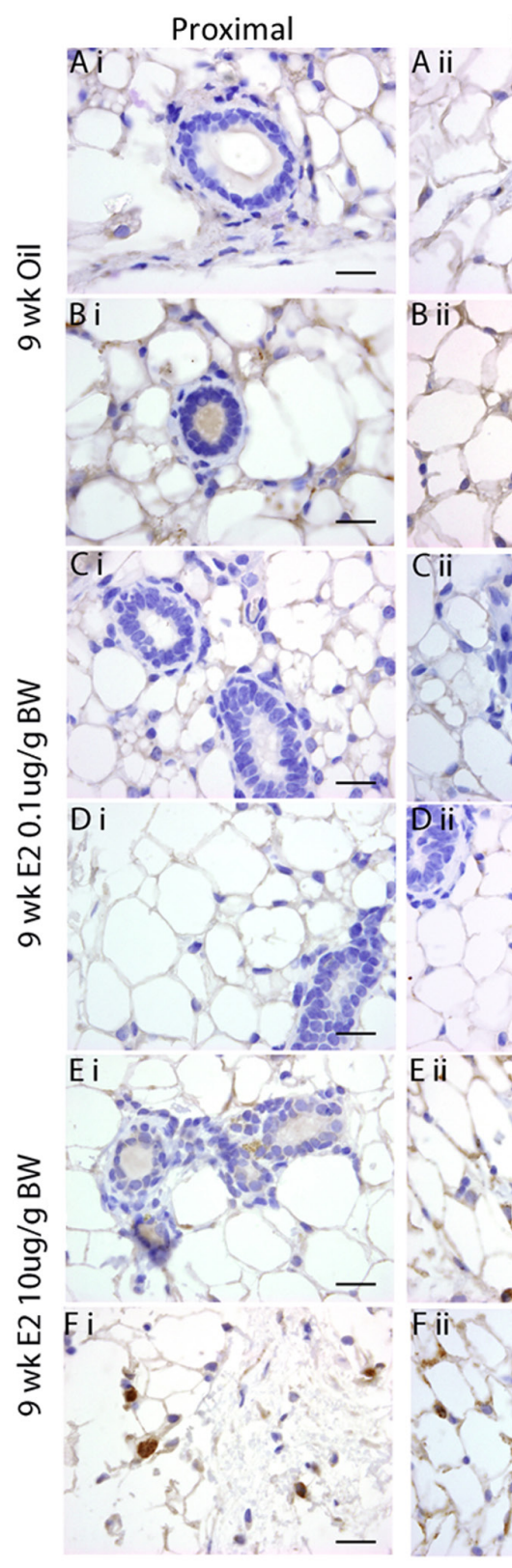

Middle
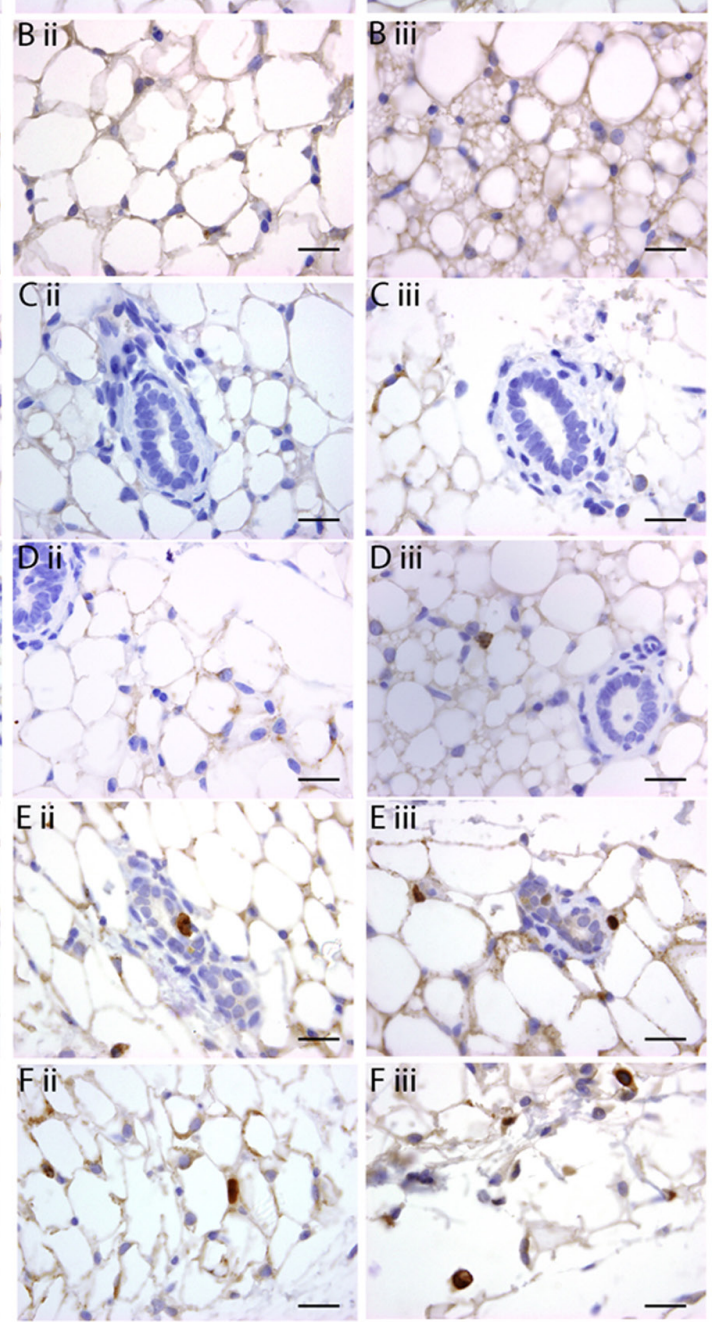

\section{Figure 5}

Low estrogen sensitivity in the epithelial mammary cells of adult (9 week old) mice. BrDU staining in the mammary glands of mice treated with either peanut oil control ( $A$ and $B$ ) or $0.1 \mu \mathrm{g} / \mathrm{g} \mathrm{BW} 17 \beta$ estradiol (C and D) or $10 \mu \mathrm{g} / \mathrm{g} / \mathrm{BW}$ ( $E$ and $F)$. Epithelial ( $A, C$ and $E$ ) and stromal staining $(B, D$ and $F)$ is shown within regions of the gland proximal (i), middle (ii) and distal (iii) to the nipple. Scale represents $20 \mu \mathrm{m}$. A full-colour version of this figure is available at https://doi. org/10.1530/JOE-17-0582.

\section{Discussion}

The normal breast is under the tight control of estrogen during growth and development. Both estrogen receptors, ER $\alpha$ and ER $\beta$, are expressed in the normal mammary gland (Saji et al. 2000) and normal human breast (Petersen et al. 1987, Clarke et al. 1997, Speirs et al. 2000, 2002, Roger et al. 2001, Shaw et al. 2002) where it is believed they work in concert to maintain control of estrogen actions. While ER $\alpha$ is critical for mediating estrogen-dependent proliferation during mammary development, ER $\beta$ inhibits cell proliferation and promotes differentiation (Thomas \& Gustafsson 2011). Here, we show that during active ductal development, ER $\alpha$ expression is high and ER $\beta$ is low correlating with a high proliferative index and high sensitivity to estrogen-induced proliferation. In contrast, at times of maintenance, ER $\alpha$ expression is low and ER $\beta$ is high which is an expression profile associated with low proliferation and lowered estrogen sensitivity. The proliferative ER expression profile is further decreased (as evidenced by decreased ER $\alpha$ and Ki67 expression and increased ER $\beta$ ) in a parous mammary gland which is known to have a decreased risk of ER+ breast cancer.

Our studies found ER $\alpha$ expression to be most abundant in the 4-week-old mouse mammary gland, consistent with previous reports on protein and RNA levels (Saji 


\begin{tabular}{l|l|l|l||} 
Journal of & G V Dall et al. & A protective ER signature & $\mathbf{2 3 7 : 3}$ \\
Endocrinology & & $\mathbf{3 3 1}$
\end{tabular}
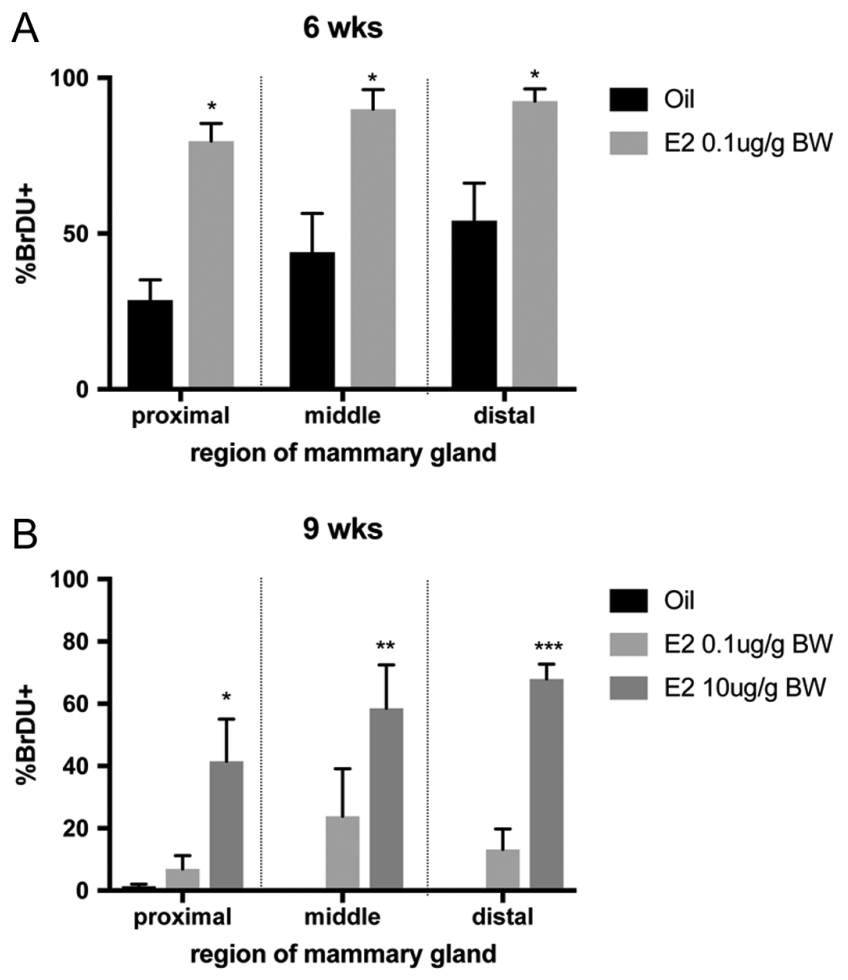

Figure 6

Quantitative assessment of BrDU staining. Mean percentage of BrDU+ epithelial cells in mice following oil or estradiol (E2) administration at (A) 6 weeks of age or (B) 9 weeks of age. ${ }^{*} P<0.05,{ }^{* *} P<0.01, * * * P<0.001$. Data are expressed as mean \pm S.E.M. according to the region of the gland assessed.

et al. 2000, Dall et al. 2017). ERo expression remained high in the 6-week-old mammary gland, particularly in the TEBs that predominate in young mice and are known to be enriched for proliferating cells (Russo et al. 1982, Dall et al. 2017). By 18 weeks of age (by this stage a wellestablished adult mammary gland), ERo expression was reduced even in the distal tips that are derived from the TEBs. In contrast, ER $\beta$ expression was highly abundant throughout all developmental stages, similar to the staining patterns observed in the normal human breast previously (Speirs et al. 2000, 2002, Shaw et al. 2002). The expression pattern of ER $\alpha$ and ER $\beta$ we report agrees with existing work showing the normal mammary gland contains a high level of ER $\beta$ - $(\sim 85 \%)$ positive epithelial cells across all ages and whilst ER $\alpha$ expression is high in young mammary glands, on average only $10 \%$ of cells in adult ducts were ER $\alpha$ positive (Petersen et al. 1987, Clarke et al. 1997, Roger et al. 2001, Saji et al. 2001).

Previous protein expression studies collectively reported a lack of co-localization between ER $\alpha$ and proliferative markers in normal mammary gland cells (Clarke et al. 1997, Russo et al. 1999, Shoker et al. 1999, Saji et al. 2000) which was unexpected given that estrogen was believed to be driving proliferation. Later studies showing the control of proliferation by ER $\alpha$ through paracrine signaling (Wiesen et al. 1999, Mallepell et al. 2006) may explain the dissociation between ER $\alpha$ and proliferation marker expression. Further, additional studies have reported the immediate degradation of the ER $\alpha$ protein following transmission of the estrogen stimulus to proliferate (Reid et al. 2003, Cheng et al. 2004, Valley et al. 2005). Our data are in support of this in that estradiol-induced proliferation seemed to be controlled

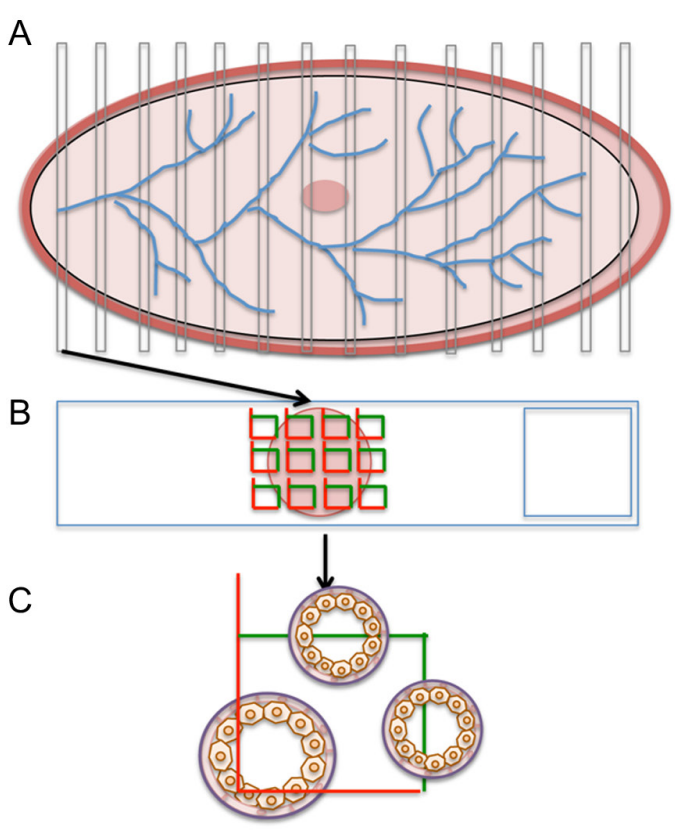

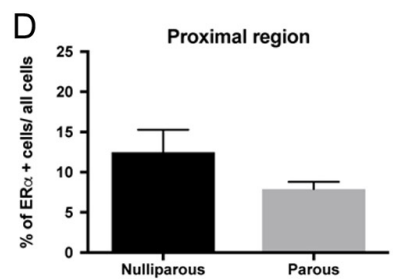
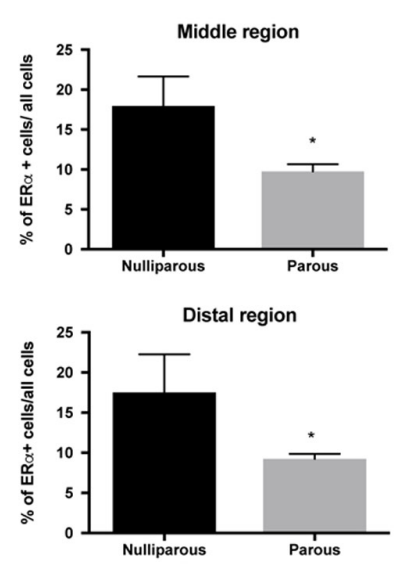

Figure 7

Stereological assessment reveals decreased estrogen receptor (ER) $\alpha$ expression in parous mammary glands. Parous or age-matched nulliparous mammary gland tissue blocks $(n=5)$ were sectioned at 4- $\mu \mathrm{m}$ sections and every 20th section was used for stereological assessment (A). Each slide had a series of sampling grids applied to it at low power (B) that were assessed at high power (C) to determine the number of positive cells. Only cells within the square or touching green (inclusion boundaries) were included. The compiled results were expressed as percentage of the number of ER $\alpha$-positive cells of all cells counted for each region of the mammary gland. Error bars represent mean \pm S.E.M. * Statistical significance $P<0.05$. A full-colour version of this figure is available at https://doi.org/10.1530/ JOE-17-0582. $\begin{array}{lr}\text { http://joe.endocrinology-journals.org } & \text { ○ } 2018 \text { Society for Endocrinology } \\ \text { https://doi.org/10.1530/JOE-17-0582 } & \text { Published by Bioscientifica Ltd. } \\ & \text { Printed in Great Britain }\end{array}$ 

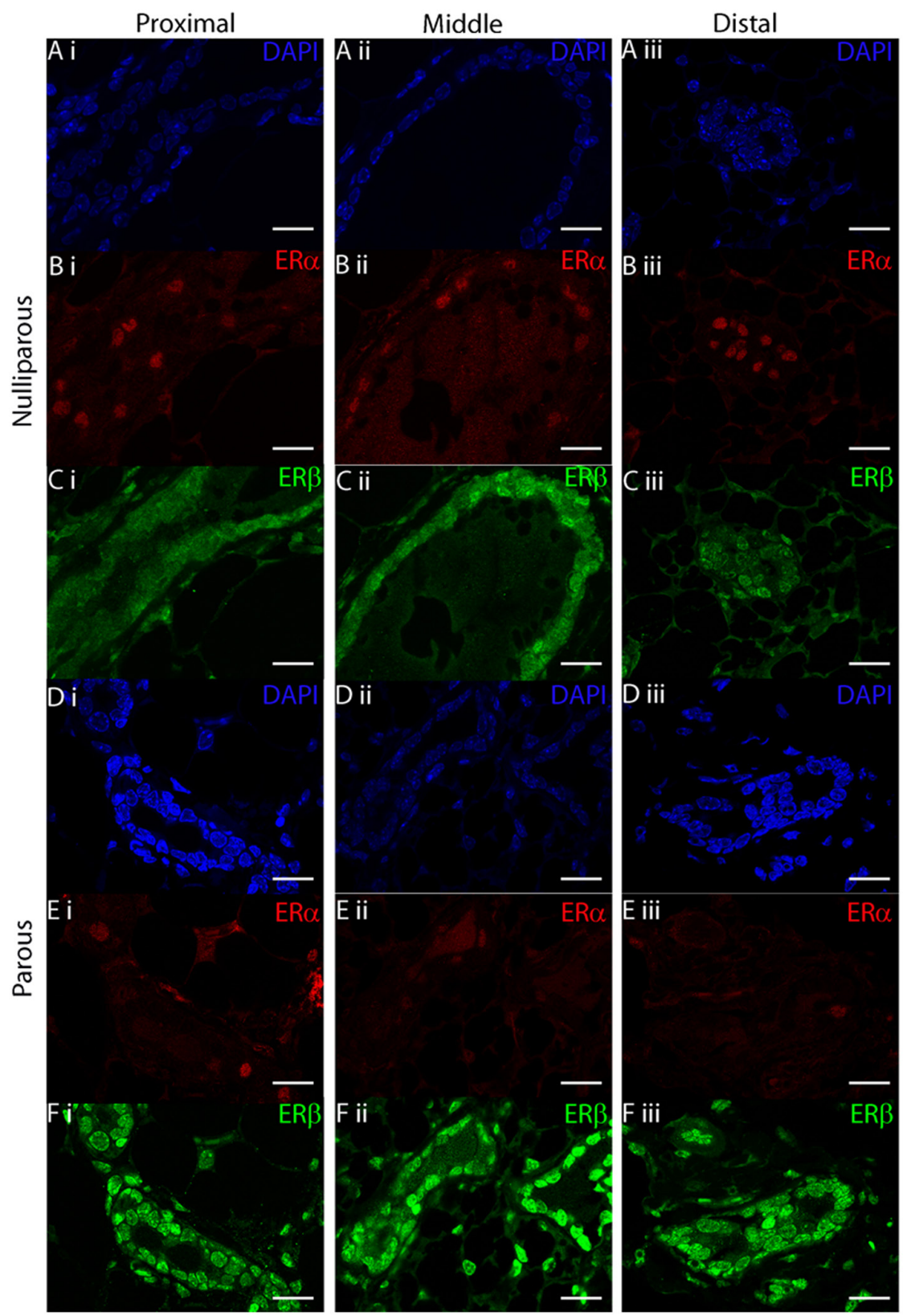

Figure 8

$\operatorname{ER} \beta$ staining intensity stronger in parous mammary glands compared to nulliparous glands. Immunofluorescence staining of DAPI (A and D), $E R \alpha(B$ and $E$ ) and $E R \beta(C$ and $F$ ) in nulliparous ( $A$, $B$ and $C$ ) and parous ( $D, E$ and F) mammary glands. Expression was assessed in various regions of the gland that were proximal (i), middle (ii) and distal (iii) to the nipple. Scale represents $20 \mu \mathrm{m}$. A full-colour version of this figure is available at $\mathrm{https} / / / \mathrm{doi} .0 \mathrm{rg} / 10.1530 / \mathrm{JOE}-17-0582$.

by ERo expression. Ki67 expression was higher in 6-weekold mammary glands compared to 18-week-old mammary glands and likewise lower levels of estradiol was able to stimulate mammary epithelial cell proliferation in ovariectomized 6-week-old mice compared to 10-weekold mice. This proliferative expression profile aligned closely with the expression of ER $\alpha$ and not ER $\beta$. ER $\alpha$ is a major prognostic factor for breast cancer. It is expressed in the majority of breast cancers and also in the breast tissue of populations at high risk of breast cancer (Lawson et al. 1999). Deregulation of ER $\alpha$ expression increases proliferation and leads to the development of ductal carcinoma in situ (Frech et al. 2005). Thus, an increased ER $\alpha$ expression in the developing mammary gland, whilst important for ductal tree outgrowth, may signify a time in the mammary gland that is vulnerable to the oncogenic events that accompany increased proliferation. Early work by Russo et al.supports such a hypothesis by reporting higher incidence rates of mammary tumors in young mice treated with a chemical carcinogen compared to their older counterparts (Russo et al. 1979). Similarly, women exposed to environmental carcinogens such as pesticides and radiation are at an increased risk of developing breast cancer later in life if they were young at the time 

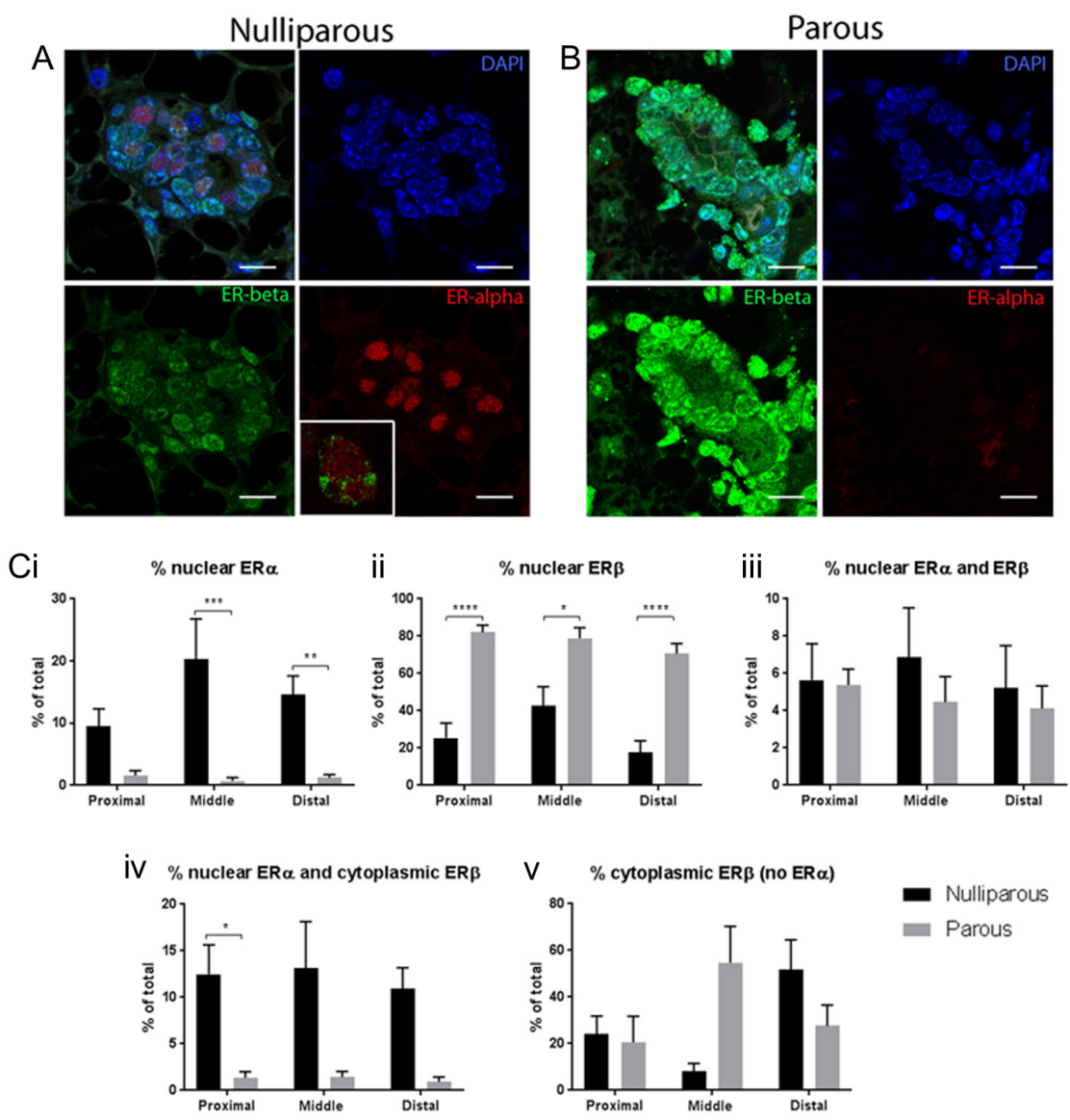

Figure 9

Parous mammary glands have a less proliferative ER profile. Representative images from nulliparous (A) and parous (B) glands stained with DAPI (blue), ER $\beta$ (green), ER $\alpha$ (red). Overlay is shown in the left hand upper corner. Scale represents $10 \mu \mathrm{m}$. (C) Quantification across the gland (proximal, middle and distal) assessing the subcellular localization of ERs including nuclear $E R \alpha$ alone (i), nuclear ER $\beta$ alone (ii), nuclear $E R \alpha$ and $\operatorname{ER} \beta$ (iii), nuclear $E R \alpha$ with cytoplasmic $\operatorname{ER} \beta$ (iv) and cytoplasmic ER $\beta$ alone (v). Data represent mean \pm S.E.M. for $n=4-5$ animals. ${ }^{*} P<0.05$, $* * * P<0.001, * * * * P<0.0001$. A full-colour version of this figure is available at https://doi. org/10.1530/JOE-17-0582. of exposure compared to those exposed at older ages (McGregor et al. 1977, Hoffman et al. 1989, Boice et al. 1991, Land et al. 2003, Cohn et al. 2007).

Providing further support for high ER $\alpha$ expression, correlating with an increased proliferative signature and higher risk of breast cancer, is the significant decrease in $\mathrm{ER} \alpha$ we observed in our parous mice, which are known to be at a decreased risk of developing ER+ tumors (Russo et al. 1991, Medina \& Smith 1999). This agrees with flow-cytometry data in mice showing a decrease in luminal Sca-1+ (luminal ER+) cells with parity (Meier-Abt et al. 2013) and human studies assessing the downstream target progesterone receptor (Muenst et al. 2017). Thus, the decreased ER $\alpha$ expression in parous mice may explain in part their decreased risk of cancer.

In estrogen-responsive breast cancer subtypes, ER $\alpha$ expression increases whilst ER $\beta$ expression decreases with increasing grade of breast cancer (Lawson et al. 1999,
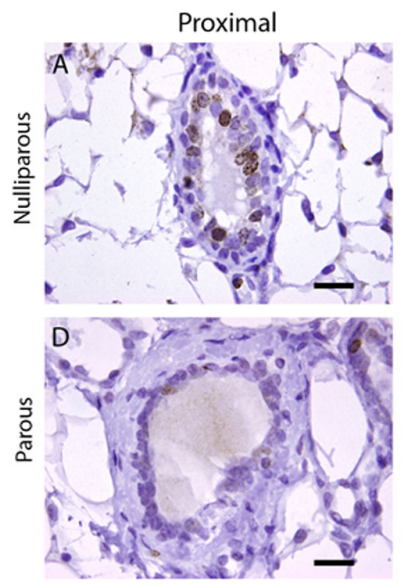

http://joe.endocrinology-journals.org https://doi.org/10.1530/JOE-17-0582
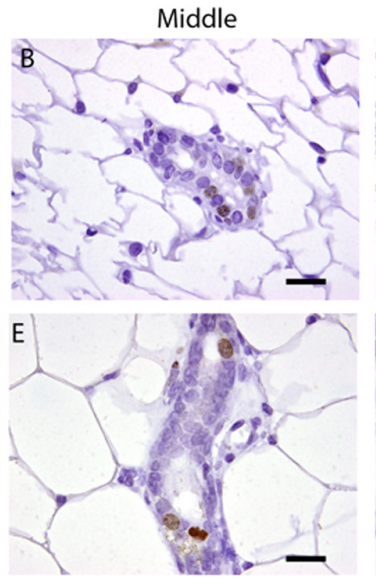

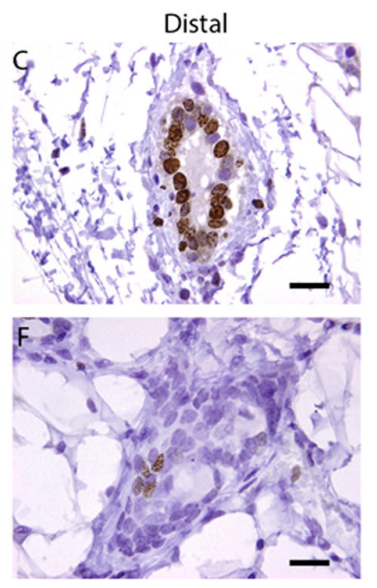

\section{Figure 10}

Proliferation levels are decreased in parous mammary glands. Ki67 staining in nulliparous (A) and parous (B) mice. Expression was assessed in various regions of the gland that were proximal (i), middle (ii) and distal (iii) to the nipple. Scale represents $20 \mu \mathrm{m}$. A full-colour version of this figure is available at https://doi.org/10.1530/ JOE-17-0582. 
Roger et al. 2001, Powell et al. 2012). Within invasive breast cancers patients with ER $\beta$-positive tumors had increased disease-free survival (Sugiura et al. 2007), which has been shown to also be independent of ER $\alpha$ status (Omoto et al. 2001, 2002). In line with this in vitro studies, we have revealed that $\mathrm{ER} \beta$ overexpression in $\mathrm{ER} \alpha+$ breast cancers inhibits estrogen-stimulated proliferation and tumor growth (Omoto et al. 2003, Paruthiyil et al. 2004, Ström et al. 2004, Behrens et al. 2007). We assessed the level of ER $\beta$ co-expression and found that in addition to the loss of nuclear ER $\alpha$-expressing cells, parous mice had a significant increase in nuclear ER $\beta$-expressing cells compared to age-matched nulliparous controls. This suggests that the lower levels of proliferation in parous individuals shown here and by others (Russo \& Russo 1996) may be due to the collaborative effects of lower levels of the pro-proliferative ER $\alpha$ and higher levels of the anti-proliferative ER $\beta$ in the gland.

The work herein shows an increase in nuclear ER $\beta$ expressing cells in parous individuals which correlates with a decrease in proliferation. This finding is somewhat supported by early in vitro work showing that overexpression, or even expression of $\operatorname{ER} \beta$ at the same levels of ER $\alpha$ in breast cancer cell lines, resulted in a decrease in proliferation following estradiol treatment (Omoto et al. 2003, Paruthiyil et al. 2004, Ström et al. 2004, Behrens et al. 2007). Whilst we did observe a decrease in ER $\alpha$ expression and increase in ER $\beta$ in the parous mammary glands, there was no difference in the percentage of cells co-expressing $\operatorname{ER} \alpha$ and $\operatorname{ER} \beta$ in the nucleus. However, we have measured ER expression and co-localization in the normal setting, which is very different to the aforementioned forced co-expression studies using breast cancer cell lines. It was interesting that we did not observe direct co-localization of ER $\alpha$ and ER $\beta$ in the same nuclear location; however, we realize that a more sensitive method such as the proximity ligation assay would be required to confirm this. This would appear to contradict theories surrounding how ER $\beta$ regulates the proliferative actions of $\mathrm{ER} \alpha$, in that they state that they are required to be expressed in the same subcellular compartment (Pettersson et al. 2000, Saji et al. 2001, Powell et al. 2012). However, we did find proliferation (as measured by Ki67) was lower in parous mammary glands (that have low ER $\alpha$ alone and high nuclear ER $\beta$ alone expression) compared to nulliparous mammary glands. Therefore, our work suggests that $\operatorname{ER} \beta$ may control ER $\alpha$ transcriptional activity without the need for direct physical interaction, but this requires further testing.
Our work shows that high ER $\alpha$ expression levels dictate the estrogen sensitivity and in turn proliferative nature of the mammary gland. We also show a lowered $\mathrm{ER} \alpha$ and higher intensity $\mathrm{ER} \beta$ expression profile in parous mice correlating with a lower level of proliferation which may explain their reduced risk of ER+ breast cancer.

\section{Supplementary data}

This is linked to the online version of the paper at https://doi.org/10.1530/ JOE-17-0582.

\section{Declaration of interest}

The authors declare that there is no conflict of interest that could be perceived as prejudicing the impartiality of the research reported.

\section{Funding}

G D was supported by an Australian Postgraduate Scholarship. K B was supported by and NBCF Early Career Fellowship, an NHMRC New Investigator grant and a VCA early career seed grant. R L A was supported by an NBCF Senior Fellowship. G R $S$ was supported by an NHMRC fellowship. J-Å G was supported by a grant from the Robert A. Welch Foundation (E-0004). L C M was supported by the Canadian Institutes of Health Research (CIHR), the Canadian Breast Cancer Research Alliance ( $C B C R A)$ and the Canadian Breast Cancer Foundation (CBCF).

\section{Acknowledgements}

The authors wish to acknowledge the Monash Micro Imaging Facility at Monash University and Centre for Advanced Histology and Microscopy at the Peter MacCallum Cancer Centre for provision of instrumentation, training and support. They also wish to thank Jill Nguyen for assistance with culturing cells.

\section{References}

Behrens D, Gill JH \& Fichtner I 2007 Loss of tumourigenicity of stably ERbeta-transfected MCF-7 breast cancer cells. Molecular and Cellular Endocrinology 274 19-29. (https://doi.org/10.1016/j.mce.2007.05.012)

Bianco JJ, McPherson SJ, Wang H, Prins GS \& Risbridger GP 2006 Transient neonatal estrogen exposure to estrogen-deficient mice (aromatase knockout) reduces prostate weight and induces inflammation in late life. American Journal of Pathology 168 1869-1878. (https://doi.org/10.2353/ajpath.2006.050623)

Bocchinfuso WP \& Korach KS 1997 Mammary gland development and tumorigenesis in estrogen receptor knockout mice. Journal of Mammary Gland Biology and Neoplasia 2 323-334. (https://doi. org/10.1023/A:1026339111278)

Bocchinfuso WP, Lindzey JK, Hewitt SC, Clark JA, Myers PH, Cooper R \& Korach KS 2000 Induction of mammary gland development in estrogen receptor-alpha knockout mice. Endocrinology 141 2982-2994. (https://doi.org/10.1210/endo.141.8.7609)

Boice JD, Preston D, Davis FG \& Monson RR 1991 Frequent chest X-ray fluoroscopy and breast cancer incidence among tuberculosis patients http://joe.endocrinology-journals.org https://doi.org/10.1530/JOE-17-0582 (c) 2018 Society for Endocrinology Published by Bioscientifica Ltd. Printed in Great Britain 
in Massachusetts. Radiation Research 125 214-222. (https://doi. org/10.2307/3577890)

Cheng G, Weihua Z, Warner M \& Gustafsson J-Å 2004 Estrogen receptors $E R \alpha$ and ER $\beta$ in proliferation in the rodent mammary gland. PNAS 101 3739-3746. (https://doi.org/10.1073/pnas.0307864100)

Clarke RB, Howell A, Potten CS \& Anderson E 1997 Dissociation between steroid receptor expression and cell proliferation in the human breast. Cancer Research 57 4987-4991.

Cohn BA, Wolff MS, Cirillo PM \& Sholtz RI 2007 DDT and breast cancer in young women: new data on the significance of age at exposure. Environmental Health Perspectives 115 1406-1414. (https://doi. org/10.1289/ehp.10260)

Dall GV, Vieusseux JL, Korach KS, Arao Y, Hewitt SC, Hamilton KJ, Dzierzak E, Boon WC, Simpson ER, Ramsay RG, et al. 2017 SCA-1 labels a subset of estrogen-responsive bipotential repopulating cells within the CD24+ CD49fhi mammary stem cell-enriched compartment. Stem Cell Reports 8 417-431. (https://doi.org/10.1016/j. stemcr.2016.12.022)

Dupont S, Krust A, Gansmuller A, Dierich A, Chambon P \& Mark M 2000 Effect of single and compound knockouts of estrogen receptors alpha (ERalpha) and beta (ERbeta) on mouse reproductive phenotypes. Development 127 4277-4291.

Enmark E, Pelto-Huikko M, Grandien K, Lagercrantz S, Lagercrantz J, Fried G, Nordenskjold M \& Gustafsson JA 1997 Human estrogen receptor beta-gene structure, chromosomal localization, and expression pattern. Journal of Clinical Endocrinology and Metabolism 82 4258-4265. (https://doi.org/10.1210/jcem.82.12.4470)

Esslimani-Sahla M, Simony-Lafontaine J, Kramar A, Lavaill R, Mollevi C, Warner M, Gustafsson JA \& Rochefort H 2004 Estrogen receptor beta (ER beta) level but not its ER beta cx variant helps to predict tamoxifen resistance in breast cancer. Clinical Cancer Research 10 5769-5776. (https://doi.org/10.1158/1078-0432.CCR-04-0389)

Feng Y, Manka D, Wagner KU \& Khan SA 2007 Estrogen receptor-alpha expression in the mammary epithelium is required for ductal and alveolar morphogenesis in mice. PNAS 104 14718-14723. (https:// doi.org/10.1073/pnas.0706933104)

Forster C, Makela S, Warri A, Kietz S, Becker D, Hultenby K, Warner M \& Gustafsson JA 2002 Involvement of estrogen receptor beta in terminal differentiation of mammary gland epithelium. PNAS 99 15578-15583. (https://doi.org/10.1073/pnas.192561299)

Frech MS, Halama ED, Tilli MT, Singh B, Gunther EJ, Chodosh LA, Flaws JA \& Furth PA 2005 Deregulated estrogen receptor alpha expression in mammary epithelial cells of transgenic mice results in the development of ductal carcinoma in situ. Cancer Research $\mathbf{6 5}$ 681-685.

Gosden JR, Middleton PG \& Rout D 1986 Localization of the human oestrogen receptor gene to chromosome $6 \mathrm{q} 24-\mathrm{q} 27$ by in situ hybridization. Cytogenetics and Cell Genetics 43 218-220. (https://doi. org/10.1159/000132325)

Gruvberger-Saal SK, Bendahl PO, Saal LH, Laakso M, Hegardt C, Eden P, Peterson C, Malmstrom P, Isola J, Borg A, et al. 2007 Estrogen receptor beta expression is associated with tamoxifen response in ERalphanegative breast carcinoma. Clinical Cancer Research 13 1987-1994. (https://doi.org/10.1158/1078-0432.CCR-06-1823)

Haslam SZ 1989 The ontogeny of mouse mammary gland responsiveness to ovarian steroid hormones. Endocrinology 125 2766-2772. (https:// doi.org/10.1210/endo-125-5-2766)

Haslam SZ \& Shyamala G 1980 Progesterone receptors in normal mammary gland: receptor modulations in relation to differentiation. Journal of Cell Biology 86 730-737. (https://doi.org/10.1083/ jcb.86.3.730)

Hewitt SC, Bocchinfuso WP, Zhai J, Harrell C, Koonce L, Clark J, Myers P \& Korach KS 2002 Lack of ductal development in the absence of functional estrogen receptor alpha delays mammary tumor formation induced by transgenic expression of ErbB2/neu. Cancer Research $\mathbf{6 2}$ 2798-2805.
Hieken TJ, Carter JM, Hawse JR, Hoskin TL, Bois M, Frost M, Hartmann LC, Radisky DC, Visscher DW \& Degnim AC 2015 ERbeta expression and breast cancer risk prediction for women with atypias. Cancer Prevention Research 8 1084-1092. (https://doi. org/10.1158/1940-6207.CAPR-15-0198)

Hoffman DA, Lonstein JE, Morin MM, Visscher W, Harris BSH \& Boice JD 1989 Breast cancer in women with scoliosis exposed to multiple diagnostic X rays. Journal of the National Cancer Institute $\mathbf{8 1}$ 1307-1312. (https://doi.org/10.1093/jnci/81.17.1307)

Krege JH, Hodgin JB, Couse JF, Enmark E, Warner M, Mahler JF, Sar M, Korach KS, Gustafsson JA \& Smithies O 1998 Generation and reproductive phenotypes of mice lacking estrogen receptor beta. PNAS 95 15677-15682. (https://doi.org/10.1073/pnas.95.26.15677)

Land CE, Tokunaga M, Koyama K, Soda M, Preston DL, Nishimori I \& Tokuoka S 2003 Incidence of female breast cancer among atomic bomb survivors, Hiroshima and Nagasaki, 1950-1990. Radiation Research 160 707-717. (https://doi.org/10.1667/RR3082)

Lawson JS, Field AS, Champion S, Tran D, Ishikura H \& Trichopoulos D 1999 Low oestrogen receptor alpha expression in normal breast tissue underlies low breast cancer incidence in Japan. Lancet $\mathbf{3 5 4}$ 1787-1788. (https://doi.org/10.1016/S0140-6736(99)04936-3)

Leygue E \& Murphy LC 2013 A bi-faceted role of estrogen receptor beta in breast cancer. Endocrine-Related Cancer 20 R127-R139. (https://doi. org/10.1530/ERC-12-0389)

Li X, Huang J, Yi P, Bambara RA, Hilf R \& Muyan M 2004 Single-chain estrogen receptors (ERs) reveal that the ER $\alpha / \beta$ heterodimer emulates functions of the ER $\alpha$ dimer in genomic estrogen signaling pathways. Molecular and Cellular Biology 24 7681-7694. (https://doi.org/10.1128/ MCB.24.17.7681-7694.2004)

Mallepell S, Krust A, Chambon P \& Brisken C 2006 Paracrine signaling through the epithelial estrogen receptor $\alpha$ is required for proliferation and morphogenesis in the mammary gland. PNAS 103 2196-2201. (https://doi.org/10.1073/pnas.0510974103)

Maneix L, Antonson P, Humire P, Rochel-Maia S, Castaneda J, Omoto Y, Kim HJ, Warner M \& Gustafsson JA 2015 Estrogen receptor $\beta$ exon 3-deleted mouse: the importance of non-ERE pathways in ER $\beta$ signaling. PNAS 112 5135-5140. (https://doi.org/10.1073/pnas.1504944112)

Masood S 1992 Estrogen and progesterone receptors in cytology: a comprehensive review. Diagnostic Cytopathology 8 475-491. (https:// doi.org/10.1002/dc.2840080508)

McGregor DH, Land CE, Choi K, Tokuoka S, Liu PI, Wakabayashi T \& Beebe GW 1977 Breast cancer incidence among atomic bomb survivors, Hiroshima and Nagasaki, 1950-69. Journal of the National Cancer Institute 59 799-811. (https://doi.org/10.1093/jnci/59.3.799)

Medina D \& Smith GH 1999 Chemical carcinogen-induced tumorigenesis in parous, involuted mouse mammary glands. Journal of the National Cancer Institute 91 967-969. (https://doi.org/10.1093/jnci/91.11.967)

Meier-Abt F, Milani E, Roloff T, Brinkhaus H, Duss S, Meyer DS, Klebba I, Balwierz PJ, van Nimwegen E \& Bentires-Alj M 2013 Parity induces differentiation and reduces Wnt/Notch signaling ratio and proliferation potential of basal stem/progenitor cells isolated from mouse mammary epithelium. Breast Cancer Research 15 R36. (https:// doi.org/10.1186/bcr3419)

Muenst S, Mechera R, Daster S, Piscuoglio S, Ng CKY, Meier-Abt F, Weber WP \& Soysal SD 2017 Pregnancy at early age is associated with a reduction of progesterone-responsive cells and epithelial Wnt signaling in human breast tissue. Oncotarget 8 22353-22360. (https:// doi.org/10.18632/oncotarget.16023)

Myers E, Fleming FJ, Crotty TB, Kelly G, McDermott EW, O'Higgins NJ, Hill AD \& Young LS 2004a Inverse relationship between ER-beta and SRC-1 predicts outcome in endocrine-resistant breast cancer. British Journal of Cancer 91 1687-1693. (https://doi.org/10.1038/ sj.bjc.6602156)

Myers M, Britt KL, Wreford NG, Ebling FJ \& Kerr JB 2004b Methods for quantifying follicular numbers within the mouse ovary. Reproduction 127 569-580. (https://doi.org/10.1530/rep.1.00095) 
Nelson AW, Groen AJ, Miller JL, Warren AY, Holmes KA, Tarulli GA, Tilley WD, Katzenellenbogen BS, Hawse JR, Gnanapragasam VJ, et al. 2017 Comprehensive assessment of estrogen receptor beta antibodies in cancer cell line models and tissue reveals critical limitations in reagent specificity. Molecular and Cellular Endocrinology 440 138-150. (https://doi.org/10.1016/j.mce.2016.11.016)

Ogawa S, Inoue S, Watanabe T, Orimo A, Hosoi T, Ouchi Y \& Muramatsu M 1998 Molecular cloning and characterization of human estrogen receptor betacx: a potential inhibitor of estrogen action in human. Nucleic Acids Research 26 3505-3512. (https://doi.org/10.1093/nar/26.15.3505)

Omoto Y, Inoue S, Ogawa S, Toyama T, Yamashita H, Muramatsu M, Kobayashi S \& Iwase H 2001 Clinical value of the wild-type estrogen receptor beta expression in breast cancer. Cancer Letters 163 207-212. (https://doi.org/10.1016/S0304-3835(00)00680-7)

Omoto Y, Kobayashi S, Inoue S, Ogawa S, Toyama T, Yamashita H, Muramatsu M, Gustafsson JA \& Iwase H 2002 Evaluation of oestrogen receptor beta wild-type and variant protein expression, and relationship with clinicopathological factors in breast cancers. European Journal of Cancer 38 380-386. (https://doi.org/10.1016/ S0959-8049(01)00383-5)

Omoto Y, Eguchi H, Yamamoto-Yamaguchi Y \& Hayashi S 2003 Estrogen receptor (ER) beta1 and ERbetacx/beta2 inhibit ERalpha function differently in breast cancer cell line MCF7. Oncogene 22 5011-5020. (https://doi.org/10.1038/sj.onc.1206787)

Paruthiyil S, Parmar H, Kerekatte V, Cunha GR, Firestone GL \& Leitman DC 2004 Estrogen receptor beta inhibits human breast cancer cell proliferation and tumor formation by causing a G2 cell cycle arrest. Cancer Research 64 423-428. (https://doi. org/10.1158/0008-5472.CAN-03-2446)

Petersen OW, Hoyer PE \& van Deurs B 1987 Frequency and distribution of estrogen receptor-positive cells in normal, nonlactating human breast tissue. Cancer Research 47 5748-5751.

Pettersson K, Delaunay F \& Gustafsson JA 2000 Estrogen receptor beta acts as a dominant regulator of estrogen signaling. Oncogene 19 4970-4978. (https://doi.org/10.1038/sj.onc.1203828)

Powell E, Shanle E, Brinkman A, Li J, Keles S, Wisinski KB, Huang W \& Xu W 2012 Identification of estrogen receptor dimer selective ligands reveals growth-inhibitory effects on cells that co-express ERalpha and ERbeta. PLOS ONE 7 e30993. (https://doi.org/10.1371/journal.pone.0030993)

Reid G, Hübner MR, Métivier R, Brand H, Denger S, Manu D, Beaudouin J, Ellenberg J \& Gannon F 2003 Cyclic, proteasomemediated turnover of unliganded and liganded ER $\alpha$ on responsive promoters is an integral feature of estrogen signaling. Molecular Cell 11 695-707. (https://doi.org/10.1016/S1097-2765(03)00090-X)

Risbridger GP, Ellem SJ \& McPherson SJ 2007 Estrogen action on the prostate gland: a critical mix of endocrine and paracrine signaling. Journal of Molecular Endocrinology 39 183-188. (https://doi. org/10.1677/JME-07-0053)

Roger P, Sahla ME, Makela S, Gustafsson JA, Baldet P \& Rochefort H 2001 Decreased expression of estrogen receptor beta protein in proliferative preinvasive mammary tumors. Cancer Research $612537-2541$.

Russo J \& Russo IH 1980 Influence of differentiation and cell kinetics on the susceptibility of the rat mammary gland to carcinogenesis. Cancer Research 40 2677-2687.

Russo IH \& Russo J 1996 Mammary gland neoplasia in long-term rodent studies. Environmental Health Perspectives 104 938-967. (https://doi. org/10.1289/ehp.96104938)

Russo J, Wilgus G \& Russo IH 1979 Susceptibility of the mammary gland to carcinogenesis: I differentiation of the mammary gland as determinant of tumor incidence and type of lesion. American Journal of Pathology 96 721-736.
Russo J, Tay LK \& Russo IH 1982 Differentiation of the mammary gland and susceptibility to carcinogenesis. Breast Cancer Research and Treatment 2 5-73.

Russo IH, Koszalka M \& Russo J 1991 Comparative study of the influence of pregnancy and hormonal treatment on mammary carcinogenesis. British Journal of Cancer 64 481-484. (https://doi.org/10.1038/ bjc.1991.335)

Russo J, Ao X, Grill C \& Russo IH 1999 Pattern of distribution of cells positive for estrogen receptor alpha and progesterone receptor in relation to proliferating cells in the mammary gland. Breast Cancer Research and Treatment 53 217-227. (https://doi. org/10.1023/A:1006186719322)

Saji S, Jensen EV, Nilsson S, Rylander T, Warner M \& Gustafsson J-Å 2000 Estrogen receptors $\alpha$ and $\beta$ in the rodent mammary gland. PNAS 97 337-342. (https://doi.org/10.1073/pnas.97.1.337)

Saji S, Sakaguchi H, Andersson S, Warner M \& Gustafsson J-AK 2001 Quantitative analysis of estrogen receptor proteins in rat mammary gland. Endocrinology 142 3177-3186. (https://doi.org/10.1210/ endo.142.7.8260)

Schedin P 2006 Pregnancy-associated breast cancer and metastasis. Nature Reviews Cancer 6 281-291. (https://doi.org/10.1038/nrc1839)

Shaw JA, Udokang K, Mosquera JM, Chauhan H, Jones JL \& Walker RA 2002 Oestrogen receptors alpha and beta differ in normal human breast and breast carcinomas. Journal of Pathology 198 450-457. (https://doi.org/10.1002/path.1230)

Shoker BS, Jarvis C, Clarke RB, Anderson E, Hewlett J, Davies MPA, Sibson DR \& Sloane JP 1999 Estrogen receptor-positive proliferating cells in the normal and precancerous breast. American Journal of Pathology 155 1811-1815. (https://doi.org/10.1016/S00029440(10)65498-3)

Speirs V, Adams IP, Walton DS \& Atkin SL 2000 Identification of wild-type and exon 5 deletion variants of estrogen receptor $\beta$ in normal human mammary gland. Journal of Clinical Endocrinology and Metabolism $\mathbf{8 5}$ 1601-1605. (https://doi.org/10.1210/jcem.85.4.6493)

Speirs V, Skliris GP, Burdall SE \& Carder PJ 2002 Distinct expression patterns of ER $\alpha$ and ER $\beta$ in normal human mammary gland. Journal of Clinical Pathology 55 371-374. (https://doi.org/10.1136/jcp.55.5.371)

Ström A, Hartman J, Foster JS, Kietz S, Wimalasena J \& Gustafsson J$\AA 2004$ Estrogen receptor $\beta$ inhibits $17 \beta$-estradiol-stimulated proliferation of the breast cancer cell line T47D. PNAS 101 1566-1571. (https://doi.org/10.1073/pnas.0308319100)

Sugiura H, Toyama T, Hara Y, Zhang Z, Kobayashi S, Fujii Y, Iwase H \& Yamashita H 2007 Expression of estrogen receptor $\beta$ wild-type and its variant $\mathrm{ER} \beta \mathrm{cx} / \beta 2$ is correlated with better prognosis in breast cancer. Japanese Journal of Clinical Oncology 37 820-828. (https://doi. org/10.1093/jjco/hym114)

Thomas C \& Gustafsson JA 2011 The different roles of ER subtypes in cancer biology and therapy. Nature Reviews Cancer 11 597-608. (https://doi.org/10.1038/nrc3093)

Valley CC, Métivier R, Solodin NM, Fowler AM, Mashek MT, Hill L \& Alarid ET 2005 Differential regulation of estrogen-inducible proteolysis and transcription by the estrogen receptor $\alpha \mathrm{N}$ terminus. Molecular and Cellular Biology 25 5417-5428. (https://doi.org/10.1128/ MCB.25.13.5417-5428.2005)

Weihua Z, Mäkelä S, Andersson LC, Salmi S, Saji S, Webster JI, Jensen EV, Nilsson S, Warner M \& Gustafsson J-A 2001 A role for estrogen receptor $\beta$ in the regulation of growth of the ventral prostate. PNAS 98 6330-6335. (https://doi.org/10.1073/pnas.111150898)

Wiesen JF, Young P, Werb Z \& Cunha GR 1999 Signaling through the stromal epidermal growth factor receptor is necessary for mammary ductal development. Development 126 335-344.

Received in final form 23 March 2018

Accepted 10 April 2018

Accepted Preprint published online 10 April 2018 http://joe.endocrinology-journals.org https://doi.org/10.1530/JOE-17-0582
(C) 2018 Society for Endocrinology Published by Bioscientifica Ltd. Printed in Great Britain 